\title{
PERFORMANCE-BASED RANK AND REMUNERATION UNIVERSITY POLICY FOR INCREASED MOTIVATION AND QUALITY
}

\author{
Veronika Kareva \\ Associate professor, Faculty of Languages, Cultures and Communication, \\ South East European University, Tetovo, North Macedonia \\ v.kareva@seeu.edu.mk \\ Abdylmenaf Bexheti \\ Full professor, Faculty of Business and Economics, \\ South East European University, Tetovo, North Macedonia \\ a.bexheti@seeu.edu.mk \\ Xhevair Memedi \\ $\mathrm{PhD}$. Faculty of Business and Economics \\ South East European University \\ x.memedi@ seeu.edu.mk
}

\begin{abstract}
Motivation plays an immense role and is one of the key factors for successful and qualitative performance in all spheres of personal and professional engagement of individuals. Therefore, educational institutions, including academia, pay special attention to finding tools for motivating students, but also for motivation of their academic staff. Increased motivation has shown to lead to better performance and better performance inevitably contributes to quality enhancement at both individual and institutional level.

The aim of this paper is to present an institutional Ranking and Remuneration (R\&R) Policy based on Key Performance Indicators (KPIs) in four areas identified as the most crucial
\end{abstract}


for successful operation of a higher education institution: teaching and learning, research, staff digital profile, service to society and project-based activities. Southeast European University (SEEU) in North Macedonia has developed KPIs in these four areas through an inclusive and transparent process based on its unique Total Quality Management (TQM) approach. The policy has been created after many consultations, trials and simulations and its main objective is to enhance institutional academic productivity and effectiveness through a human resource vibration that starts from individual evaluation, motivation and performance differentiation and leads to stimulation for achieving excellence. It is at an initial stage and if tested well in practice, it can serve as a model for other higher education institutions in the country and wider.

Key words: Policy, Motivation, Quality, Key Performance Indicators in Education

\section{INTRODUCTION}

The general practice of higher education consists of education, research, university operations and external community (Cortese, 2003) and these segments do not function as separate activities. Since students learn and are affected by everything around them, the crucial university experiences are part of a completely integrated system. None of the aforementioned elements works in isolation but they are all interrelated and have multiple functions and influences. The university practice in the modern world changes together with the common trends in the society induced by the technological revolution and globalization. It is among the main Commission priorities for the period from 2019 to 2024 to make Europe fit for the digital age and to create quality job market for young people (European Commission, 2021). Unlike the situation in the past when universities were solely educational institutions and they had scientific and intellectual goals not necessarily dependent from the societal requirements, nowadays, it is imposed on them to create skilled work force that will match the needs of the job market in the society in which they function. This, according to Kromydas (2017), is the so-called mass form of higher education, "which transmits the knowledge and skills acquired in higher education into the technical and economic roles students subsequently perform in the labor market" (p.2). Accordingly, Quality Assurance (QA) at higher education institutions should contain processes and mechanisms that will ensure fulfilling the expectations of all stakeholders involved in the process, including students, the teaching staff, support services' staff, parents, the local society, etc. In the literature about QA in general, this is most often referred to as fitness for purpose (Parri, 2006), meaning the level achieved by a certain product 
or service in accomplishing the preset goals. Contemporary universities can remain to be competitive on the vast and diversified educational market today only if they manage to deliver high quality education, for which they need to undergo internal reforms and restructuring.

Based on these circumstances, our assumption is that a well-designed and practically tested QA system, spread to all areas of university functioning will lead to higher staff performance due to their better motivation for work. Enhanced performance is expected to be followed by enriched learning experiences and greater student satisfaction.

It seems that this "win, win" situation is difficult to achieve, but the Southeast European University (SEEU) in North Macedonia is on a good way to challenge it by adopting a specific Ranking and Remuneration (R\&R) Policy based on Key Performance Indicators (KPI) in the areas that are crucial for university operation. Defining the areas, the instruments for measurement and the indicators have been enabled through the institutional well developed Quality Assurance (QA) system based on Total Quality Management (TQM) model.

\section{INSTITUTIONAL TQM FOR QUALITY ENHANCEMENT}

TQM as a concept was derived from business, but later its popularity was spread to many other services. Nowadays it is accepted as a common management instrument applicable to organizations of any kind. The founder of the concept is Deming who promoted it as an instrument for achieving excellence in business in 1950s (Sohel-UzZaman, Anjalin, 2016). According to Deming, (1993) application of TQM in higher education institutions will enable them to stay competitive; it will reduce the number of badly organized or conducted activities; it will help universities to focus on the market needs, achieve excellent results and meet the requirements of all involved parties/stakeholders. If applied at universities, the basics of TQM will not only assure the highest possible services for students, but they will also contribute towards better use of the staff capacities. At the same time, the institution will manage to achieve a high level of satisfaction and motivation for work by its two key players: students and staff. Kareva and Memedi (2021) conclude that TQM makes it possible for the university to develop a QA system that will touch upon and influence every segment of its operation. Such a system includes quality within the three basic areas of university functioning: teaching, learning and research and it expands further to the quality of student and staff support. All these efforts are aimed at taking the maximum from the opportunities for learning and doing research: "Instead of one person or unit being in charge of teaching and learning, TQM best optimizes participants within the organization at all levels" (Sabet et al, 2012, p. 209). 
The literature points out that when TQM is applied in education, students should be treated as equal to any other clients or customers in business or services and thus their satisfaction becomes a very relevant factor contributing to the organizational quality. Gilbert, Keck and Simmpson (1993) identify four constituent elements of TQM: quality as defined by the clients or customers (in the educational context - students); the highest management incentive and responsibility for quality improvement; enhanced quality as a result of the systematic analysis of the processes within the organization and the constant efforts for quality improvement at general organizational level. If these elements are transferred in educational settings, they are not supposed to interfere with the academic freedom of universities since the application of TQM does not mean imposing selected teaching methods. Setting TQM at universities can only contribute to creating better learning conditions for students and it is not aimed at achieving uniformity.

Another customer-based TQM model for educational organizations is offered by Harris, 1994 (in Ali and Shastri, 2009). In this model, similarly to the previous one, students and their satisfaction have a primary focus. The academic and support staff and the ways they contribute to the effectiveness of the institution also have a role, together with the complete educational service with the measurement instruments created for checking the institutional success. Creating measurement instruments of different kinds, keeping and comparing data, following and analyzing trends and identifying areas for improvement are among the suggestions for TQM in education offered by other researchers (Michael, Sower, and Motwani 1997, in Rabah, 2015).

The literature further indicates that introducing TQM in educational institutions necessitates involvement of every single individual towards constant improvement. This systematic approach to QA requires application of both procedural and transformational methods. (Sallis, 1993). The procedural method refers to providing evidence that certain activities and practices have been carried out according to a previous plan, based on indicators of measurable performance. Transformational concept involves some not so easily defined quality features, such as for example, customer care and social responsibility which are difficult to measure.

SEEU approach towards QA follows the best identified practices for QA based on TQM and focuses on instruments for measuring the teaching and learning, research activities, staff digital profile and community outreach activities (also called project-based activities). This 
system has been developed, refined and improved for more than 15 years to culminate in the last two academic years with establishing KPIs for measuring academic performance in the aforementioned categories. Every category contains rubrics defining grades from 1 to 5 (1 being the weakest and 5 being the strongest) that have been incorporated into the R\&R Policy.

\section{MEASURING ACADEMIC PERFORMANCE}

The category of teaching and learning contains grades from two instruments: teaching observation and student evaluation. The teaching observation is an institutional process through which every academic staff member is annually observed by a peer and graded from 1 to 5 on several segments related to teaching and learning: preparation, class management, methodology, interaction, and assessment. There is a rubric for every question and area that clearly defines the evaluation criteria for the observed class activities. Student evaluation is conducted online at the end of every semester but before the exams and it allows students to evaluate anonymously their professors and courses on a scale from 1 to 5 .

The category of digitalization has received a great attention because of the global trends. This has turned to be very useful during the lockdown period. SEEU utilizes Google Classroom learning management platform, and its use is obligatory and regularly monitored. Thus, 50 points, or grade 5 are allocated for section one (consisting of preparation, clarity, and relevance of the digital course - 30 points) and maximum 20 points for section two (including interaction, assessment and feedback).

Research activities represent the third category, and it has been the most difficult to quantify because of the specificity of different disciplines and the long and unpredictable publication process. It has been done in accordance with the national legislation and University Rules for research activities and promotion into academic titles. The following table illustrates the grades based on the point allocation from research activities and scientific publications. This is the only category that applies to two years. 


\begin{tabular}{|l|l|l|l|l|l|l|}
\hline $\begin{array}{l}\text { Academic } \\
\text { title }\end{array}$ & \multicolumn{5}{|c|}{ Grade } \\
\hline Docent & $\mathbf{1}$ & $\mathbf{2}$ & $\mathbf{3}$ & $\mathbf{4}$ & $\mathbf{4 , 5}$ & $\mathbf{5}$ \\
\hline $\begin{array}{l}\text { Associate } \\
\text { Professor }\end{array}$ & 0 & $1-6$ & Min.7 & Min.10 & Min.12 & 1 IF \\
\hline $\begin{array}{l}\text { Full } \\
\text { Professor }\end{array}$ & 0 & $1-8$ & Min.9 & Min.13 & Min.15 & 1 IF \\
\hline
\end{tabular}

The last category - project-based activities allows the greatest freedom to the Deans to evaluate their staff on a scale from 1 to 5 based on their participation in scientific projects, but also based on their involvement in any community outreach activities, such as different debates and discussions with the public, consultations and services to the University and society, participation in promotional activities etc. provided they are evidence based.

\section{RANKING AND REMUNERATION (R\&R) POLICY}

Together with some academic policies the R\&R policy is among the first policies the University created in the year of its inception. Back then it was a rudimentary legal instrument to govern the compensation system of the institution. It was completely egalitarian in form recognizing academic titles which defined the salary levels. It had no structure which would account for the additional load, complexity of the job done or performance of the academic staff. Very quickly it was clear that this is not an adequate instrument to cater to the aspirations of the newly founded institution to grow and develop. Soon a spin-off version of this embryonic form of the policy was developed with an intention to create a modern policy which will enable the institution to attract qualitative workforce, reward it accordingly and help its retention. Some novelty features of the policy determined reward levels for the complexity of particular jobs or for additional load which in the then undeveloped high education system in Republic of North Macedonia was frequently the case. Performance compensation remained out of this version and of the next one introduced in 2009.

The new R\&R policy of the University determines a salary structure which accounts for all legal requirements as well as for the achievement of the strategic goals of the university. It recognizes and values the contribution of all staff towards the success of the university. It is an objective remuneration system which aims to eliminate discrimination on grounds of gender, 
ethnicity, disability, sexual orientation. The pay spine it uses is a differentiated one to support all staff categories.

There are separate provisions to define the elements of the salary. The main pillar of the system remains the base salary which is egalitarian in nature and remains the same for all staff within an academic rank (for example any Associate Professor has an 800.-€ monthly net base salary). Apart from this main pillar the policy has other compensation elements which complement the base salary and are variable in nature. One such element is experience. This element has been introduced in accordance with legal requirements but at the same time it recognizes service to the university and rewards loyalty. The value of this element is $0,5 \%$ of the net base salary added for each year of service. Another variable element is workload related. It recognizes significant additional workload or responsibility and is consistent with the rank of the post holder. The payments for this variable are made for a specified period for as long as the additional workload happens (for example for additional teaching hours, academic staff is remunerated for as long as the semester goes on).

The main variable element in the R\&R policy is the Performance. It stands there to recognize and reward individual performance. This variable element consists of four indicators. One of the indicators is the Teaching observation and student evaluation. The Teaching observation is conducted by adequate peers of the observed staff and each of the observed elements of this indicator is marked with a grade from 1-5. The student evaluation is done and graded, too with a grade from 1-5, by students through a thoroughly anonymous process. These two grades are combined to yield a single grade for this indicator. The next indicator is the Research. Each academic staff's research portfolio is continuously monitored and appropriately evaluated with points based on kinds of research. The sum of the points yields a definite grade between 1 and 5. The third indicator inserted in the performance variable is the Digital profile. Each academic staff's digital profile is monitored by the corresponding dean to see the volume and quality of digital activities. It is expected that each professor posts materials online (Google classroom) as well as interact with students to facilitate their learning process. Materials include course syllabus, presentations, videos, tests quizzes and other adequate materials for the course. Based on the quality and quantity of the Digital profile this indicator is also attributed a grade from 1 to 5. The final indicator is the Project \& Consulting. It includes all activities of an academic staff with an impact to the society such as a project, participation in public debates, consulting of governmental institutions or businesses, various public duties for a specified period. The grade, as with the other indicators is between 1 and 5 . 
The monetary value of the payment for performance is in the amount of up to $1 / 3$ of the monthly base salary. Each of the indicators above has a weight in the performance variable. The weight for Teaching observation and student evaluation has been fixed to $35 \%$. $30 \%$ weight has been assigned to the indicator for research. The indicator for Digital profile scores a weight of $35 \%$. Currently the Project \&Consulting indicator has the lowest weight, and it is $15 \%$, however it is foreseen that all indicators and grading criteria be reviewed each year so that adjustments towards achievement and fulfillment of strategic goals can be accomplished.

In the table below we can see the information on the rank, value of net base salary, and payment for additional workload and for performance. We should note here that the values for workload and performance are the maximal ones. Workload remuneration is paid as in the table only if the staff has 4 teaching hours in addition or equivalent. Currently this variable is paid to most of staff as the majority of them have additional teaching hours. Performance remuneration can be paid as in the table provided all elements are graded with five, meaning that only in rare cases performance remuneration will be paid as in the table.

\begin{tabular}{|c|c|c|c|c|c|c|c|c|}
\hline \multirow{2}{*}{ Family } & \multirow{2}{*}{ Rank } & \multirow{2}{*}{$\begin{array}{c}\text { Net } \\
\text { base } \\
\text { salary }\end{array}$} & \multicolumn{2}{|c|}{ Additional remuneration } & \multicolumn{4}{|c|}{$\begin{array}{c}\text { Performance - based on following } \\
\text { indicator }\end{array}$} \\
\hline & & & Workload & Performance & $\begin{array}{l}\text { TO\& } \\
\text { SE }\end{array}$ & Research & $\begin{array}{l}\text { Digital } \\
\text { Profile }\end{array}$ & $\begin{array}{l}\text { Project \& } \\
\text { Consulting }\end{array}$ \\
\hline Lector & $\mathbf{R 4}$ & 400 & 25 & 115 & \multicolumn{4}{|c|}{$\begin{array}{c}\text { Definitive value of indicator in accordance } \\
\text { with grade and weight }\end{array}$} \\
\hline Assistant & R4 & 400 & 50 & 150 & \multicolumn{4}{|c|}{$\begin{array}{c}\text { Definitive value of indicator in accordance } \\
\text { with grade and weight }\end{array}$} \\
\hline High Lector & R5 & 500 & 35 & 125 & \multicolumn{4}{|c|}{$\begin{array}{c}\text { Definitive value of indicator in accordance } \\
\text { with grade and weight }\end{array}$} \\
\hline Docent & R6 & 600 & 100 & 200 & \multicolumn{4}{|c|}{$\begin{array}{c}\text { Definitive value of indicator in accordance } \\
\text { with grade and weight }\end{array}$} \\
\hline $\begin{array}{l}\text { Associate } \\
\text { Professor }\end{array}$ & $\mathbf{R 7}$ & 800 & 150 & 250 & \multicolumn{4}{|c|}{$\begin{array}{l}\text { Definitive value of indicator in accordance } \\
\text { with grade and weight }\end{array}$} \\
\hline
\end{tabular}




\begin{tabular}{|c|c|c|c|c|c|}
\hline \multirow[t]{2}{*}{$\begin{array}{l}\text { Full } \\
\text { Professor }\end{array}$} & R8 1 & 800 & 150 & 250 & $\begin{array}{l}\text { Definitive value of indicator in accordance } \\
\text { with grade and weight }\end{array}$ \\
\hline & R8 2 & 1000 & 200 & 300 & $\begin{array}{l}\text { Definitive value of indicator in accordance } \\
\text { with grade and weight }\end{array}$ \\
\hline
\end{tabular}

Table 2. Pay spine, academic staff. All values are expressed in $€$.

\section{SIMULATION}

The following two tables are an extract from an array of simulations that were run during the creation process of the policy. They show a real case example of an Associate Professor and his/her compensation in the current remuneration system and the new one. It can be observed that he/she with the present performance will be able to get 220.- $€$ out of the maximum of 250.-€.

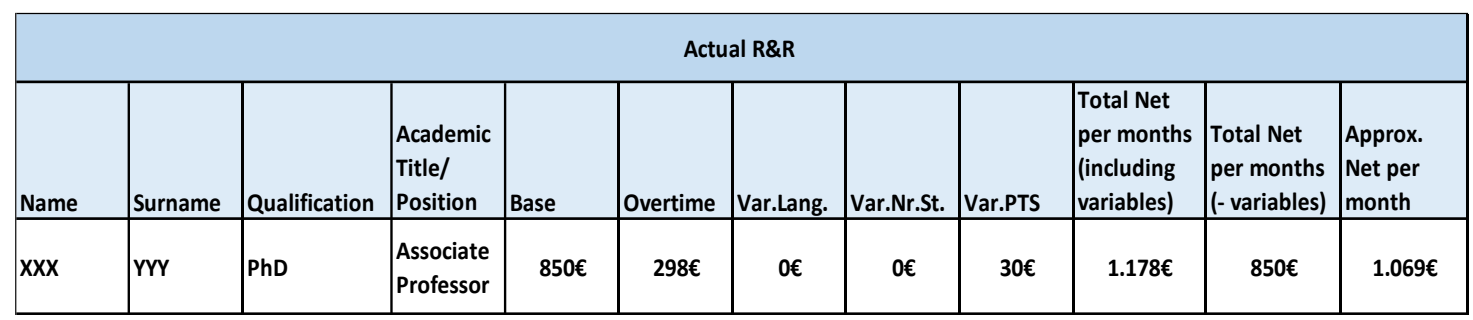

Table 3. Actual R\&R

\begin{tabular}{|c|c|c|c|c|c|c|c|c|c|c|c|c|}
\hline \multicolumn{13}{|c|}{ R\&R Proposal } \\
\hline Name & Surname & Qualification & $\begin{array}{l}\text { Academic } \\
\text { Title/ } \\
\text { Position }\end{array}$ & Base & Workload & $\begin{array}{c}\text { TO\&SE } \\
35 \%\end{array}$ & $\begin{array}{c}\text { Research } \\
\mathbf{3 0} \%\end{array}$ & $\begin{array}{c}\text { Digital } \\
\text { Profile } \\
25 \%\end{array}$ & $\begin{array}{c}\text { Project } \\
\text { \&Consulting } \\
15 \%\end{array}$ & \begin{tabular}{|l|} 
Total Net \\
per months \\
(including \\
variables)
\end{tabular} & $\mid \begin{array}{l}\text { Total Net } \\
\text { per months } \\
\text { (-workload) }\end{array}$ & $\begin{array}{l}\text { Approx. } \\
\text { Net per } \\
\text { month }\end{array}$ \\
\hline$x x x$ & YYY & PhD & $\begin{array}{l}\text { Associate } \\
\text { Professor }\end{array}$ & $800 €$ & $150 €$ & $88 €$ & $56 €$ & $38 €$ & $38 €$ & $1.169 €$ & $1.019 €$ & $1.119 €$ \\
\hline
\end{tabular}

Table 4. Proposed R\&R 


\section{CONCLUSION}

Creating a performance-based mechanism for awarding the best and stimulating them though motivation for even better results has been a very advanced and courageous activity, especially in academic settings and it has normally created many dilemmas, questions, reactions, and opposition by certain people. The University management has been all the time aware of this and they have therefore organized wide consultations and debates about the whole process. All comments and suggestions have been taken into consideration and another simulation has been done before the system is put into practice, starting from September 2021. Fortunately, SEEU has already established a high-quality culture and awareness among its staff, students, and other stakeholders and this has helped a lot. The aim is motivational and stimulating and people have understood that the management initiative is genuine; that is oriented towards quality enhancement as the only way to attract more students in the highly competitive educational market in the country and region. The future steps will include creation of follow up activities in order to measure the effect of the new policy and if the outcomes are positive, SEEU initiative can be followed by other higher education institutions. 


\section{REFERENCES}

Ali, M.; Shastri, R.K. (2009). 'Implementation of Total Quality Management in Higher Education'. Asian Journal of Business Management. 2(1): 9-16, 2010 ISSN: 2041-8752

Cortese, A. (2003). 'The Critical Role of Higher Education in Creating a Sustainable Future'. PHEJ March-May 03. Retrieved 2021-07-06 from

http://citeseerx.ist.psu.edu/viewdoc/download?doi=10.1.1.739.3611\&rep=rep1\&type=pdf

Deming, W.E. (1993) Total Quality Management in Higher Education. Management Services, 35 .

European Commission. https://ec.europa.eu/info/strategy/priorities-2019-2024_en

Gilbert, J. P., Keck, K.L., and Simpson, R.D. (1993). Imroving the Process of . Total

Quality Management for the College Classroom. Innovative Higher Education. 18/1.

Kareva, V., Memedi, Xh. (2021). Total Quality Management (TQM) for Changes of Staff

Capacity in Higher Education. A Model to Follow in the Public Sector.

International Journal of Public Sector Performance Management (IJPSPM), Vol. 7, No.4.

Kromydas, T. (2017). Rethinking Higher Education and its Relationship with Social Inequalities: Past Knowledge, Present State and Future Potential. Palgrave Communications. 3/1.

Parri, J. (2006). Quality in Higher Education'. Vadyba/Management. 2006 m. Nr 2(11).

Rabah, I. (2015). Total Quality Management in Higher Education. Global Journals Vol. 15.

Sabet, S.H.; Saleki, Z.S.; Roumi B.; Dezfoulian A. (2012). 'A Study on Total Quality Management in Higher Education Industry in Malaysia'. International Journal of Business and Social Science 3/17.

Sallis, E. (1993). Total Quality Management in Education. Taylor and Francis E-Library 2005.

Sohel-Uz-Zaman, A.S.Md. and Anjalin, U. (2016) Implementing Total Quality Management in Education: Compatibility and Challenges. Open Journal of Social Sciences , 4, pp207-217. 